\title{
European Journal of Archaeology
}

Print ISSN 1461-9571, Online ISSN 1741-2722

\section{Subscription information}

For information and subscription rates please see www.tandfonline.com/pricing/journal/yeja

Taylor \& Francis has a flexible approach to subscriptions enabling us to match individual libraries' requirements. This journal is available via a traditional institutional subscription (either print with online access, or online only at a discount) or as part of our subject collections or full text packages. For more information on our sales packages please visit www.tandfonline.com/page/librarians

All current institutional subscriptions include online access for any number of concurrent users across a local area network to the currently available backfile and articles posted online ahead of publication.

Subscriptions purchased at the personal rate are strictly for personal, non-commercial use only. The reselling of personal subscriptions is prohibited. Personal subscriptions must be purchased with a personal cheque or credit card. Proof of personal status may be requested.

Back issues: Taylor \& Francis retains a two-year back issue stock of joumals. Older volumes are held by our official stockists to whom all orders and enquiries should be addressed: Periodicals Service Company, 351 Fairview Ave., Suite 300, Hudson, New York 12534, USA. Tel: +1 518537 4700; fax: +1 518537 5899; email: psc@periodicals.com.

Ordering information: Please contact your local Customer Service Department to take out a subscription to the Journal: USA, Canada: Taylor \& Francis, Inc., 325 Chestnut Street, 8th Floor, Philadelphia, PA 19106, USA. Tel: +1 800354 1420; Fax: +1 215625 2940. UK/ Europe/Rest of World: T\&F Customer Services, Informa UK Ltd, Sheepen Place, Colchester, Essex, CO3 3LP, United Kingdom. Tel: +44 (0) 207017 5544; Fax: +44 (0) 207017 5198; Email: subscriptions@tandf.co.uk.

Dollar rates apply to all subscribers outside Europe. Euro rates apply to all subscribers in Europe, except the UK and the Republic of Ireland where the pound sterling price applies. If you are unsure which rate applies to you please contact Customer Services in the UK. All subscriptions are payable in advance and all rates include postage. Journals are sent by air to the USA, Canada, Mexico, India, Japan and Australasia. Subscriptions are entered on an annual basis, i.e. January to December. Payment may be made by sterling cheque, dollar cheque, euro cheque, international money order, National Giro or credit cards (Amex, Visa and Mastercard).

US Postmaster: Please send address changes to YEJA, clo Air Business Ltd, c/o Worldnet Shipping Inc., 156-15 146th Avenue, 2nd Floor, Jamaica, NY 11434, USA. Periodicals postage paid at Jamaica NY 11431.

Subscription records are maintained at Taylor \& Francis Group, 4 Park Square, Milton Park, Abingdon, OX14 4RN, United Kingdom.

\section{Disclaimer}

Informa UK Limited, trading as Taylor \& Francis Group, make every effort to ensure the accuracy of all the information (the Content) contained in our publications. However, Informa UK Limited, trading as Taylor \& Francis Group, our agents, and our licensors make no representations or warranties whatsoever as to the accuracy, completeness, or suitability for any purpose of the Content. Any opinions and views expressed in this publication are the opinions and views of the authors, and are not the views of or endorsed by Informa UK Limited, trading as Taylor \& Francis Group. The accuracy of the Content should not be relied upon and should be independently verified with primary sources of information. Informa UK Limited, trading as Taylor \& Francis Group, shall not be liable for any losses, actions, claims, proceedings, demands, costs, expenses, damages, and other liabilities whatsoever or howsoever caused arising directly or indirectly in connection with, in relation to or arising out of the use of the Content. Terms \& Conditions of access and use can be found at www.tandfonline.com/page/terms-and-conditions

Informa UK Limited, trading as Taylor \& Francis Group, grants authorization for individuals to photocopy copyright material for private research use, on the sole basis that requests for such use are referred directly to the requestor's local Reproduction Rights Organization (RRO). The copyright fee is $€ 30.00 / € 36.00 / \$ 48.00$ exclusive of any charge or fee levied. In order to contact your local RRO, please contact International Federation of Reproduction Rights Organizations (IFRRO), rue du Prince Royal, 87, B-1050 Brussels, Belgium; email: iffro@skynet.be; Copyright Clearance Center Inc., 222 Rosewood Drive, Danvers, MA 01923, USA; email: info@copyright.com; or Copyright Licensing Agency, 90 Tottenham Court Road, London, W1P 0LP, UK; email: cla@cla.co.uk. This authorization does not extend to any other kind of copying, by any means, in any form, for any purpose other than private research use.

The print edition of this journal is typeset by Nova Techset Private Limited, Bengaluru and Chennai, India. Printed and bound by Charlesworth Press, Wakefield, UK. 
Volume 19

Number 4

\section{6}

\begin{tabular}{l|l}
$\mathbf{A}$ & $\begin{array}{l}\text { European Association } \\
\text { A }\end{array}$ \\
of Archaeologists
\end{tabular}

www. e-a-a.org

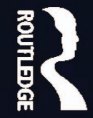

Routledge

Taylor \& Francis Group

\section{European Journal of Archaeology}

EDITORIAL

Robin Skeates

Articles

Hunting High and Low: Postglacial Colonization

Strategies in Central Norway between 9500 and 8000 cal BC Heidi M. Breivik and Martin Callanan

The Life and Times of the House: Multi-Scalar Perspectives on Settlement from the Neolithic of the Northern

Alpine Foreland

Daniela Hofmann, Renate Ebersbach,

Thomas Doppler and Alasdair Whittle

Organizing the Production of Variscite Personal Ornaments in Later Prehistoric Iberia: The Mines of Aliste and the Production Sites of Quiruelas de Vidriales (Zamora, Spain) Rodrigo Villalobos García and Carlos P. Odriozola

Textile Production in Iron Age Thrace Bela Dimova

The Ritual Use of Brooches in Early Medieval Forts on Öland, Sweden Jan-Henrik Fallgren and John Ljungkvist

The Dutch Great Stink: The End of the Cesspit Era in the Pre-Industrial Towns of Leiden and Haarlem Roos van Oosten

Sherds of Paradise: Domestic Archaeology and Ceramic Artefacts from a Protestant Mission in the South Pacific

James L. Flexner and Andrew C. Ball 